\title{
Response of soil respiration to short-term experimental warming and precipitation pulses over the growing season in an alpine meadow on the Northern Tibet
}

\author{
Zhen-Xi Shen ${ }^{1}$, Yun-Long $\mathrm{Li}^{1}$, Gang Fu ${ }^{*}$ \\ Lhasa Plateau Ecosystem Research Station, Key Laboratory of Ecosystem Network Observation and Modeling, Institute of Geographic Sciences and Natural
} Resources Research, Chinese Academy of Sciences, Beijing 100101, China

\section{A R T I C L E I N F O}

\section{Article history:}

Received 22 April 2014

Received in revised form 23 July 2014

Accepted 25 January 2015

Available online 4 February 2015

\section{Keywords:}

Climatic warming

Precipitation pulses

Soil respiration

Temperature sensitivity

Tibetan Plateau

\begin{abstract}
A B S T R A C T
A warming and precipitation pulses experiment was conducted in an alpine meadow of Tibet over the growing season (June-September) in 2013. Soil respiration $\left(R_{\mathrm{s}}\right)$ was measured biweekly from early July to early September 2013. The effect of experimental warming on $R_{\mathrm{s}}$ varied with water availability. The effect of precipitation pulses on $R_{\mathrm{s}}$ depended on pulses sizes, antecedent precipitation and soil moisture conditions. Precipitation pulses increased the temperature sensitivity of $R_{\mathrm{s}}$, which was not affected by experimental warming. Our findings suggest that water availability regulates the response of soil respiration to warming.
\end{abstract}

(c) 2015 Elsevier B.V. All rights reserved.
The Tibetan Plateau is one of the most sensitive regions to climatic change and the alpine meadow on this Plateau is one of the most sensitive vegetation types (IPCC, 2013). For example, Fu et al., 2014b showed that the response of plant photosynthesis and biomass to climatic warming over the Tibetan Plateau was greater than that of the global average. Precipitation pulses and climatic warming can trigger series responses of soils and plants, such as ecosystem and soil respiration increases (Chen et al., 2008; Shi et al., 2006; Wu et al., 2011), soil microbial biomass and activity increases (Huxman et al., 2004; Lu et al., 2013), and plant photosynthesis and biomass increases (Fu et al., 2014b; Hao et al., 2010; Wu et al., 2011). Soil respiration $\left(R_{\mathrm{s}}\right)$ constitutes one of the largest carbon fluxes in terrestrial carbon cycle (Raich and Schlesinger, 1992; Rustad et al., 2001; Wu et al., 2011). Understanding the effects of warming and precipitation pulses on $R_{S}$ is vital for predicting future changes of carbon cycle in alpine regions.

The main objectives of this study were to examine the effects of short-term experimental warming and precipitation pulses on $R_{\mathrm{S}}$ and the temperature sensitivity of $R_{\mathrm{s}}$. Previous studies showed that precipitation pulses increased $R_{\mathrm{s}}$ and the warming effects on $R_{\mathrm{s}}$

\footnotetext{
* Corresponding author. Tel.: +86 10 64889802; fax: +86 1064854230

E-mail address: fugang@igsnrr.ac.cn (G. Fu).

1 The author contributed equally to this work.
}

were regulated by water availability in arid and semi-arid ecosystems (Liu et al., 2009; Munson et al., 2010). Moreover, precipitation pulse significantly increased ecosystem respiration in an alpine meadow on the Northern Tibet (Shi et al., 2006). Thus, we hypothesized that water availability regulated the response of $R_{\mathrm{s}}$ to warming and precipitation pulses could increase $R_{\mathrm{s}}$. The effects of precipitation pulses exhibited nonlinear increases with pulse sizes (Cable et al., 2008; Huxman et al., 2004; Sponseller, 2007). Our previous study demonstrated that the correlations between $R_{\mathrm{s}}$ and soil moisture varied with water availability in an alpine meadow of Tibet (Fu et al., 2010). Therefore, we also hypothesized that the response of $R_{\mathrm{S}}$ to precipitation pulses varied with initial soil moisture condition.

The study area $\left(30^{\circ} 30^{\prime} \mathrm{N}, 91^{\circ} 04^{\prime} \mathrm{E}\right)$ is located at the Damxung Grassland Observation Station, Tibet Autonomous Region, China. Detailed descriptions of the climate, soil and vegetation conditions can be found in our previous studies (Fu et al., 2012; Yu et al., 2014). Briefly, annual mean air temperature is $1.3^{\circ} \mathrm{C}$. Annual mean rainfall is approximate $476.8 \mathrm{~mm}$. The soil is classified as sandy loam, with organic matter of $0.3-11.2 \%$ and total nitrogen of $0.03-0.49 \%$. The vegetation is Kobresia-dominated alpine meadow.

In this study, nine open-top chambers (OTCs) were randomly set up in the experimental area $(25 \mathrm{~m} \times 50 \mathrm{~m})$ in June 2013 to increase the temperature in warming treatments by trapping solar energy (Marion et al., 1997). The bottom and top diameters and the height of the OTCs were $1.45,1.00$ and $0.40 \mathrm{~m}$, respectively 
(Fu et al., 2013). There was one unwarmed plot in the vicinity of each OTC. The nine warmed and unwarmed plots were assigned randomly for three levels of precipitation pulses. Precipitation pulses was provided with hand sprinklers on June 27, July 6, July 24, August 5, August 20 and September 4, 2013. Considering a $5 \mathrm{~mm}$ increase of precipitation may offset experimental warminginduced soil drying and daily maximum total precipitation of approximate $20 \mathrm{~mm}$ in the experimental area, the three precipitation levels were 0,5 and $20 \mathrm{~mm}$ on each day of water addition. That is, the increases were about 0, 6 and $25 \%$ for the three levels of water addition over the whole growing season (June-September). There were a total of 18 experimental plots and six treatments: control ( $C$; unwarmed plot $+0 \%$ precipitation level), warm $(W$; warmed plot $+0 \%$ precipitation level), increased precipitation at a low level (LP; unwarmed plot $+6 \%$ precipitation level), warm plus increased precipitation at a low level $(W+\mathrm{LP}$; warmed plot $+6 \%$ precipitation level), increased precipitation at a high level (HP; unwarmed plot $+25 \%$ precipitation level) and warm plus increased precipitation at a high level $(W+\mathrm{HP}$; warmed plot $+25 \%$ precipitation level).

We measured soil temperature $\left(T_{\mathrm{s}}\right)$ at a depth of $5 \mathrm{~cm}$ and soil moisture (SM) at a depth of $10 \mathrm{~cm}$ for all treatments during the entire study period. We measured $R_{\mathrm{s}}$ using a $\mathrm{CO}_{2}$ flux system with a survey chamber of $20 \mathrm{~cm}$ in diameter (LI-8100, LI-COR Biosciences, Lincoln, NE, USA) (Fu et al., 2014a) after the application of water addition on July 6, July 24, August 5, August 20 and September 4, 2013. The SM in the experimental area was in a range from $0.04 \mathrm{~m}^{3} \mathrm{~m}^{-3}$ to $0.30 \mathrm{~m}^{3} \mathrm{~m}^{-3}$ over the growing season. The $\mathrm{SM}$ values on the five measuring occasions (Fig. 1) covered the moisture range and were divided into three ranges (i.e., $<0.10 \mathrm{~m}^{3}$ $\mathrm{m}^{-3}$, between 0.10 and $0.20 \mathrm{~m}^{3} \mathrm{~m}^{-3}$, and $>0.20 \mathrm{~m}^{3} \mathrm{~m}^{-3}$ ). Our previous study showed that the dependence of $R_{\mathrm{S}}$ on SM changed with the three SM ranges (Fu et al., 2010). These results implied that the five measuring occasions can reflect the relationship between initial SM and the pulse effects on $R_{\mathrm{s}}$. Before the measurement of $R_{\mathrm{s}}$, polyvinyl chloride (PVC) collars (diameter, $20 \mathrm{~cm}$; height, $5 \mathrm{~cm}$ ) were inserted approximately $2-3 \mathrm{~cm}$ into the soil for all plots. The insertion of PVC collars into soil can create airtight seals between the LI-8100 survey chamber and the soil.

For a specific measuring date, repeated-measures ANOVA was used to estimate the main and interactive effects of measuring time, experimental warming and precipitation pulses on $R_{\mathrm{s}}, T_{\mathrm{s}}$ and SM, respectively (Table 1 ). Student-Newman-Keuls multiple comparisons were performed among the three precipitation pulses, before which repeated-measures ANOVA with experimental warming and precipitation pulses as between-subject and with
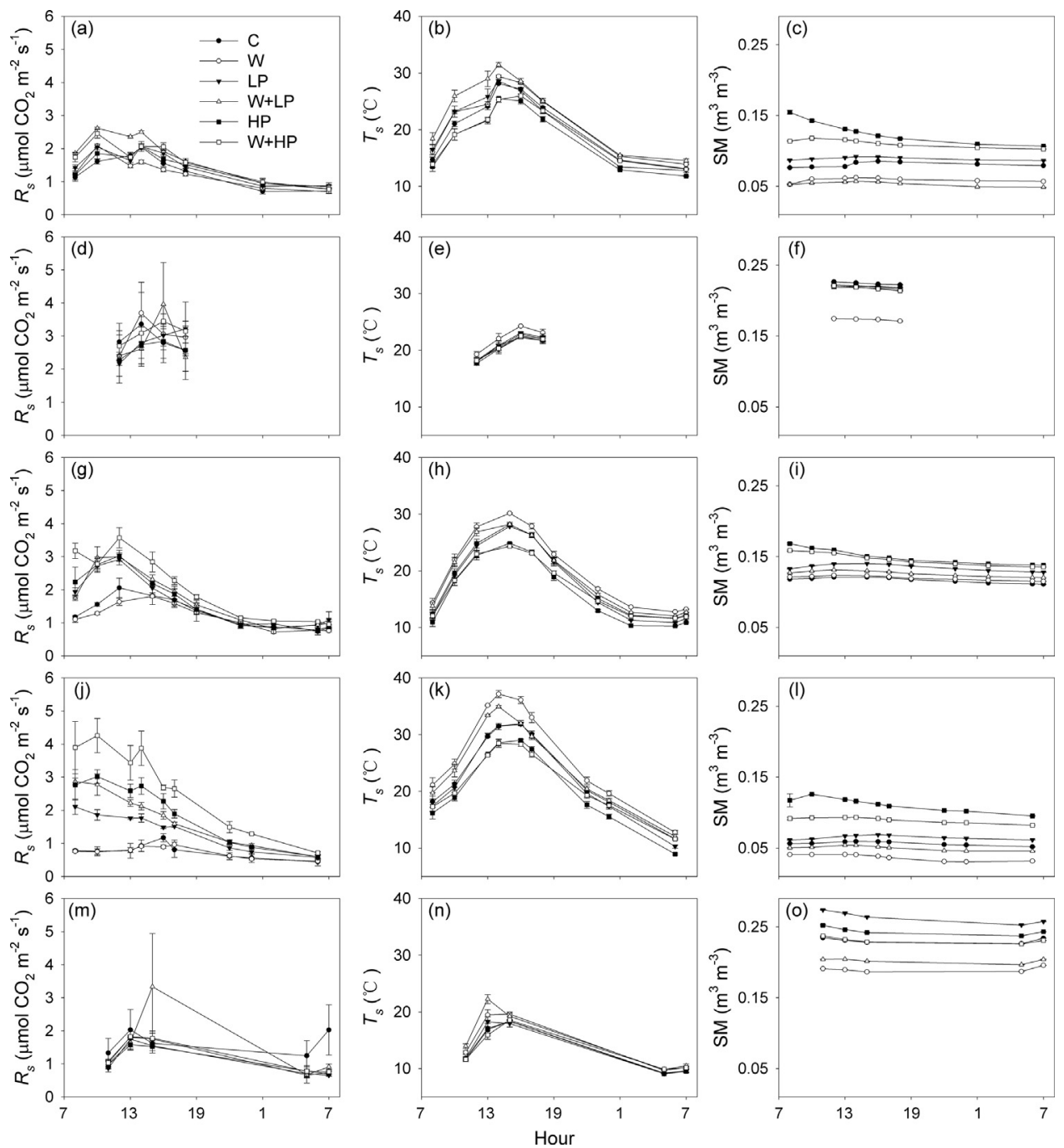

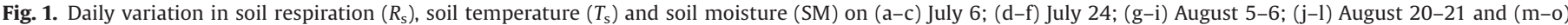

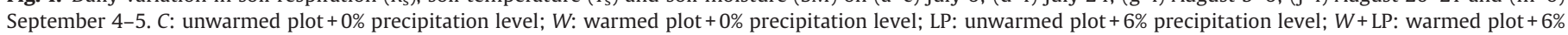
precipitation level; HP: unwarmed plot $+25 \%$ precipitation level; $W+$ HP: warmed plot $+25 \%$ precipitation level. 
Table 1

Repeated-measures ANOVA for the main and interactive effects of measuring time $(T)$, experimental warming $(W)$ and precipitation pulses (PP) on soil respiration $\left(R_{\mathrm{S}}\right)$ soil temperature $\left(T_{\mathrm{s}}\right)$ and soil water content $(\mathrm{SM})(n=3)$.

\begin{tabular}{|c|c|c|c|c|c|c|c|c|}
\hline Date & & W & PP & $T$ & $W \times \mathrm{PP}$ & $W \times T$ & $\mathrm{PP} \times T$ & $W \times \mathrm{PP} \times 1$ \\
\hline \multirow[t]{3}{*}{ July 6} & $R_{\mathrm{S}}$ & 1.14 & 1.16 & $11.2^{\mathrm{c}}$ & 0.49 & 1.00 & 0.19 & 0.52 \\
\hline & $T_{\mathrm{s}}$ & $16.3^{\mathrm{b}}$ & $17.2^{\mathrm{C}}$ & $470^{c}$ & 2.01 & 0.04 & 2.48 & 0.65 \\
\hline & SM & $4394^{c}$ & $8246^{\mathrm{C}}$ & $78^{c}$ & $173^{c}$ & $113^{c}$ & $362^{c}$ & $131^{\mathrm{c}}$ \\
\hline \multirow[t]{3}{*}{ July 24} & $R_{\mathrm{s}}$ & 0.33 & 0.05 & $3.0^{\mathrm{a}}$ & 0.13 & 0.49 & 0.93 & 0.68 \\
\hline & $T_{\mathrm{s}}$ & 4.50 & 2.74 & $76.2^{\mathrm{c}}$ & $10.5^{\mathrm{b}}$ & 0.19 & 0.12 & 0.16 \\
\hline & SM & $3918^{c}$ & $2021^{c}$ & $337^{c}$ & $2990^{c}$ & $4.6^{\mathrm{c}}$ & $2.8^{\mathrm{a}}$ & $25.6^{c}$ \\
\hline \multirow[t]{3}{*}{ August 5-6 } & $R_{\mathrm{S}}$ & 1.63 & $30.1^{c}$ & $152^{\mathrm{C}}$ & 3.73 & 1.60 & $13.8^{c}$ & 1.64 \\
\hline & $T_{\mathrm{s}}$ & $154^{\mathrm{c}}$ & $264^{c}$ & $839^{c}$ & $10.4^{\mathrm{b}}$ & 1.48 & 2.77 & 0.89 \\
\hline & SM & $487^{c}$ & $13742^{c}$ & $1864^{\mathrm{C}}$ & $8.4^{\mathrm{c}}$ & $506^{c}$ & $456^{\mathrm{c}}$ & $24.4^{c}$ \\
\hline \multirow{3}{*}{$\begin{array}{l}\text { August 20- } \\
21\end{array}$} & $R_{\mathrm{s}}$ & $27.7^{c}$ & $144^{\mathrm{c}}$ & $35.1^{\mathrm{c}}$ & $8.6^{\mathrm{b}}$ & 1.22 & $7.4^{\mathrm{c}}$ & 0.47 \\
\hline & $T_{\mathrm{s}}$ & $1013^{c}$ & $1520^{c}$ & $847^{c}$ & $155^{\mathrm{c}}$ & 2.46 & $4.1^{\mathrm{a}}$ & 2.77 \\
\hline & SM & $6588^{c}$ & $20016^{c}$ & $52.1^{\mathrm{c}}$ & $69.9^{c}$ & 1.19 & $8.3^{\mathrm{b}}$ & $6.6^{\mathrm{a}}$ \\
\hline \multirow{3}{*}{$\begin{array}{l}\text { September } \\
\quad 4-5\end{array}$} & $R_{\mathrm{s}}$ & 0.31 & 0.24 & $14.6^{\mathrm{b}}$ & 0.86 & 2.08 & 1.21 & 0.81 \\
\hline & $T_{\mathrm{s}}$ & $23.7^{c}$ & $11.2^{\mathrm{b}}$ & $491^{\mathrm{c}}$ & $6.4^{\mathrm{a}}$ & 1.43 & $6.5^{\mathrm{a}}$ & 2.48 \\
\hline & SM & $15723^{c}$ & $3172^{c}$ & $994^{\mathrm{c}}$ & $2109^{c}$ & $97.4^{c}$ & $70.9^{c}$ & $21.6^{c}$ \\
\hline
\end{tabular}

a Mean significant at 0.05 level.

b Mean significant at 0.01 level.

c Mean significant at 0.001 level.

measuring time as within-subject were conducted. For each treatment, a stepwise multiple regression analysis was used to analyze the relationships between $R_{\mathrm{S}}$ and $T_{\mathrm{S}}$ and SM (Table 2), before which natural-logarithm transformations were made for $R_{\mathrm{s}}$ and SM. We analyzed the sensitivity of $R_{\mathrm{S}}$ to temperature for each treatment using all measurement data according to:

$R_{\mathrm{S}}=a e^{b T_{\mathrm{s}}}$

where $a$ is the intercept of $R_{\mathrm{S}}$ when $T_{\mathrm{S}}$ is $0^{\circ} \mathrm{C}$, and $b$ reflects the temperature sensitivity of $R_{s}$. The $b$ values were used to calculate the respiration quotient $\left(Q_{10}\right)$

$Q_{10}=e^{10 b}$

One-way ANOVA was used to test the main and interactive effects of experimental warming and precipitation pulses on the temperature sensitivity of $R_{s}$. In addition, we also analyzed the simple linear relationship between $R_{\mathrm{S}}$ and SM. All statistical tests were produced with the SPSS software (version 16.0; SPSS Inc., Chicago, IL, USA).

Regardless of precipitation pulses, experimental warming significantly increased average $R_{\mathrm{s}}$ by $29.6 \%\left(0.41 \mu \mathrm{mol} \mathrm{m}^{-2} \mathrm{~s}^{-1}\right)$ on August 20 and 21, but had negligible effects on average $R_{\mathrm{S}}$ for the other measuring dates (Table 1, Fig. 1). However, non-significant differences were found between the $C$ and $W$ treatment for all the five measuring dates. Average $R_{\mathrm{S}}$ of the $W+\mathrm{LP}$ treatment was $34.3 \%$ $\left(0.48 \mu \mathrm{mol} \mathrm{m}^{-2} \mathrm{~s}^{-1}, p<0.01\right)$ greater than that of the LP treatment, while that of the $W+\mathrm{HP}$ treatment was $38.4 \%\left(0.76 \mu \mathrm{mol} \mathrm{m}^{-2} \mathrm{~s}^{-1}\right.$, $p<0.01$ ) higher than that of the HP treatment on August 20-21 (Fig. 1j). These results implied that the significant warming effect on $R_{\mathrm{S}}$ was mainly due to the significant changes under water addition conditions. Moreover, these findings also suggested that warming effects on $R_{\mathrm{s}}$ differed with water availability (Lellei-Kovács et al., 2008; Liu et al., 2009). Experimental warming significantly increased $T_{\mathrm{s}}$ by $1.36,0.41,1.24,1.89$ and $1.12^{\circ} \mathrm{C}$ on July 6 , July 24 , August 5-6, August 20-21 and September 4-5, respectively (Table 1, Fig. 1). In contrast, experimental warming significantly decreased SM by $0.03,0.02,0.003,0.02$ and $0.04 \mathrm{~m}^{3} \mathrm{~m}^{-3}$ on July 6 , July 24 , August 5-6, August 20-21 and September 4-5, respectively (Table 1, Fig. 1). Specifically, experimental-warming-induced soil
Table 2

Stepwise multiple regression analyses between soil respiration $\left(R_{\mathrm{S}}\right)$ and soil temperature $\left(T_{\mathrm{s}}\right)$ and soil moisture $(\mathrm{SM})$, showing changes in the regression coefficient, significance probability $(p)$, coefficient of determination $\left(R^{2}\right)$ and partial correlation coefficient. Natural logarithm transformations were made for $R_{\mathrm{S}}$ and SM prior to regression analysis. $C$ : unwarmed plot $+0 \%$ precipitation level; $W$ : warmed plot $+0 \%$ precipitation level; $L P$ : unwarmed plot $+6 \%$ precipitation level; $W+L P$ : warmed plot $+6 \%$ precipitation level; HP: unwarmed plot $+25 \%$ precipitation level; $W+$ HP: warmed plot $+25 \%$ precipitation level.

\begin{tabular}{|c|c|c|c|c|c|}
\hline Treatmen & & Coefficient & $R^{2}$ & Partial correlation & $p$ \\
\hline \multirow[t]{3}{*}{ C } & Constant & 1.28 & & & $<0.001$ \\
\hline & $T_{\mathrm{s}}$ & 0.04 & 0.20 & 0.56 & $<0.001$ \\
\hline & SM & 0.87 & 0.36 & 0.73 & $<0.001$ \\
\hline \multirow[t]{3}{*}{ W } & Constant & 0.79 & & & $<0.001$ \\
\hline & $T_{\mathrm{s}}$ & 0.04 & 0.29 & 0.63 & $<0.001$ \\
\hline & SM & 0.62 & 0.28 & 0.73 & $<0.001$ \\
\hline \multirow[t]{3}{*}{ LP } & Constant & 0.09 & & & 0.619 \\
\hline & $T_{\mathrm{s}}$ & 0.05 & 0.34 & 0.66 & $<0.001$ \\
\hline & SM & 0.35 & 0.11 & 0.40 & $<0.001$ \\
\hline \multirow[t]{3}{*}{$W+L P$} & Constant & -0.06 & & & 0.759 \\
\hline & $T_{\mathrm{s}}$ & 0.06 & 0.37 & 0.67 & $<0.001$ \\
\hline & SM & 0.3 & 0.09 & 0.37 & $<0.001$ \\
\hline \multirow[t]{3}{*}{ HP } & Constant & 0.03 & & & 0.895 \\
\hline & $T_{\mathrm{s}}$ & 0.07 & 0.52 & 0.76 & $<0.001$ \\
\hline & SM & 0.43 & 0.06 & 0.34 & $<0.001$ \\
\hline \multirow[t]{3}{*}{$W+\mathrm{HP}$} & Constant & -0.28 & & & 0.21 \\
\hline & $T_{\mathrm{s}}$ & 0.08 & 0.52 & 0.74 & $<0.001$ \\
\hline & SM & 0.27 & 0.03 & 0.23 & $<0.05$ \\
\hline
\end{tabular}

drying can dampen the positive effect of warming on $R_{\mathrm{S}}$ (LelleiKovács et al., 2008; Liu et al., 2009), which in turn resulted in non-significant warming effects on $R_{\mathrm{s}}$ under the condition of natural precipitation. In other words, soil moisture regulated the response of $R_{\mathrm{s}}$ to warming (Table 2 ).

Regardless of experimental warming, average $R_{\mathrm{S}}$ was increased by $35.7 \%\left(0.47 \mu \mathrm{mol} \mathrm{m}^{-2} \mathrm{~s}^{-1}\right)$ and $52.1 \%\left(0.68 \mu \mathrm{mol} \mathrm{m}^{-2} \mathrm{~s}^{-1}\right)$, and by $119.4 \%\left(0.90 \mu \mathrm{mol} \mathrm{m}^{-2} \mathrm{~s}^{-1}\right)$ and $214.5 \%\left(1.61 \mu \mathrm{mol} \mathrm{m}^{-2} \mathrm{~s}^{-1}\right)$ under the low and high sizes of the pulse on August 5-6 and August 20-21, respectively, but non-significant differences were found for the other measuring dates (Table 1, Fig. 1). Average $T_{\mathrm{s}}$ was significantly decreased by 0.73 and $2.71^{\circ} \mathrm{C}$, and by 1.17 and $3.91{ }^{\circ} \mathrm{C}$ under the low and high sizes of the pulse on August 5-6 and August 20-21, respectively (Table 1 , Fig. $1 \mathrm{~h}$ and $\mathrm{k}$ ). The high size of the pulse significantly decreased $T_{\mathrm{s}}$ by 1.75 and $0.77^{\circ} \mathrm{C}$ on July 6 and September 4-5, respectively, while the low size of the pulse had little effects on $T_{\mathrm{s}}$ (Table 1, Fig. $1 \mathrm{~b}$ and $\mathrm{n}$ ). In addition, average $T_{\mathrm{s}}$ tended to be decreased by 0.45 and $0.51^{\circ} \mathrm{C}$ under the low and high sizes of the pulse on July 24, respectively (Table 1, Fig. 1e). In contrast, average SM was significantly increased by 0.002 and $0.05 \mathrm{~m}^{3} \mathrm{~m}^{-3}$, by 0.02 and $0.02 \mathrm{~m}^{3} \mathrm{~m}^{-3}$, by 0.01 and $0.03 \mathrm{~m}^{3} \mathrm{~m}^{-3}$, by 0.01 and $0.05 \mathrm{~m}^{3} \mathrm{~m}^{-3}$, and by 0.02 and $0.03 \mathrm{~m}^{3} \mathrm{~m}^{-3}$ under the low and high sizes of the pulse on July 6, July 24, August 5-6, August 20-21 and September 4-5, respectively (Table 1, Fig. 1).

There were non-significant interactive effects of precipitation pulses and measuring time on July 6, July 24 and September 4-5, indicating that no pulse effects on $R_{\mathrm{s}}$ were found on the three measuring dates. The antecedent SM values were higher than $0.20 \mathrm{~m}^{3} \mathrm{~m}^{-3}$ on July 24 and September $4-5$, but less than $0.10 \mathrm{~m}^{3} \mathrm{~m}^{-3}$ on July 6. Precipitation lasted continuously two days and 13 days prior to the pulse on July 6 and September 4-5. In contrast, precipitation pulse effects on $R_{\mathrm{S}}$ lasted approximately 6-7h and 9-10 h under the low and high size of the pulse, respectively, on August 5-6. Precipitation pulse effects on $R_{\mathrm{S}}$ lasted approximately $15-16 \mathrm{~h}$ under the low size of the pulse on August 20-21. Under the high size of the pulse on August 20-21, 


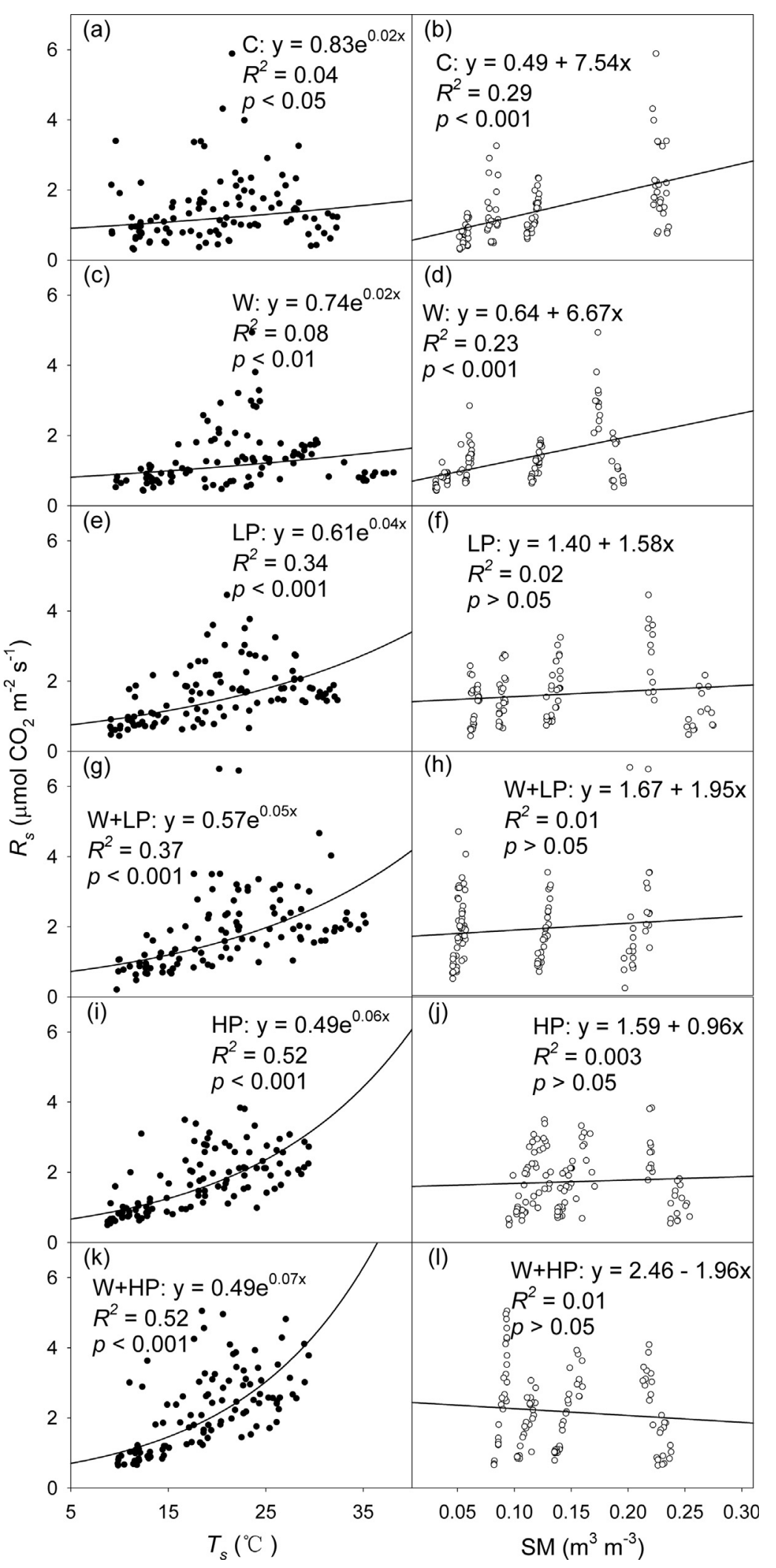

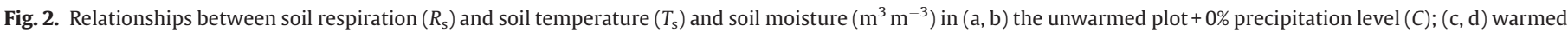

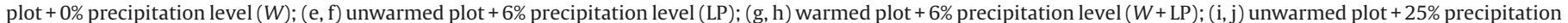
level $(\mathrm{HP}) ;(\mathrm{k}, \mathrm{l})$ warmed plot $+25 \%$ precipitation level $(W+\mathrm{HP})$.

precipitation pulse effects on $R_{\mathrm{S}}$ may exceed $24 \mathrm{~h}$. The antecedent SM values were within $0.10-0.15 \mathrm{~m}^{3} \mathrm{~m}^{-3}$ and less than $0.10 \mathrm{~m}^{3} \mathrm{~m}^{-3}$ on August 5-6, August 20-21, respectively. Non-precipitation lasted continuously seven and eight days prior to the pulse on August 5-6 and August 20-21. Our finding that the precipitation pulse significantly increased $R_{\mathrm{S}}$ after continuous drought was in 
line with previous studies which were conducted in arid and semi-arid ecosystems (Cable et al., 2008; Chen et al., 2008; Huxman et al., 2004; Sponseller, 2007).

Specifically, our finding that precipitation pulse effects on $R_{\mathrm{S}}$ varied with measuring date may be attributed to different antecedent soil moisture and precipitation conditions (Cable et al., 2008; Huxman et al., 2004). The pulse-induced magnitude and duration of the increase in $R_{\mathrm{S}}$ depended on pulse size (Chen et al., 2008; Sponseller, 2007), and initial soil moisture and precipitation conditions (Cable et al., 2008; Huxman et al., 2004). That is, the wet initial water conditions reduced or even masked the response of $R_{\mathrm{S}}$ to the pulse, while the dry initial water conditions strengthened the responses of $R_{\mathrm{S}}$ to the pulse. Similarly, the sensitivity of $R_{\mathrm{s}}$ to soil moisture was more responsive in dry conditions (Liu et al., 2009; Wu et al., 2011). In addition, larger pulses caused greater respiration rates and durations, whereas the magnitudes and durations increased nonlinearly with pulse sizes (Cable et al., 2008; Huxman et al., 2004; Sponseller, 2007). The nonlinear increases probably resulted from the following reasons. First, a greater decline in soil temperature was found in this study when there was more extra precipitation. Second, soil microbial activity was limited by carbon and nitrogen availability at a short-term timescale (Sponseller, 2007). Third, the process rates in deeper soil layer were greatly decreased (Sponseller, 2007). Fourth, higher initial water availability dampened or even masked the pulse effect (Cable et al., 2008).

Soil respiration significantly increased with $T_{\mathrm{s}}$ for all the six treatments, whereas it only had a positive relationship with SM for the $C$ and $W$ treatments (Fig. 2). Soil temperature explains the most variation of $R_{\mathrm{S}}$ for the HP and $W+$ HP treatments, the second most variation for the LP and $W+$ LP treatments and the least variation for the $C$ and $W$ treatments (Fig. 2). Soil moisture explained more variation of $R_{\mathrm{s}}$ than $T_{\mathrm{s}}$ for the $C$ treatment, while $T_{\mathrm{s}}$ explained more variation for all the other five treatments in the multiple regression equations (Table 2 ). In addition, the partial correlation coefficient between $R_{\mathrm{S}}$ and SM was greater than that between $R_{\mathrm{S}}$ and $T_{\mathrm{S}}$ for the $C$ and $W$ treatment, while the partial correlation coefficient between $R_{\mathrm{S}}$ and $T_{\mathrm{S}}$ was greater for the other four treatments (Table 2).

The net effects of experimental warming and precipitation pulses on $R_{\mathrm{S}}$ were determined by the relative strengths of the positive and negative effects on $T_{\mathrm{s}}$ and SM due to treatments (Lellei-Kovács et al., 2008; Munson et al., 2010; Zhou et al., 2006). Experimental warming and precipitation pulses altered the relative importance of soil temperature and moisture in controlling the variation of $R_{\mathrm{s}}$ (Table 2).

Experimental warming and its interaction with precipitation pulses had little effect on $Q_{10}(F=3.92, p=0.07$ for warming; $F=0.68, p=0.52$ for the interaction). In contrast, $Q_{10}$ increased significantly with precipitation pulses $(F=61.66, p<0.001)$. In detail, there were no significant differences in $Q_{10}$ between $C$ and $W$ treatments, between LP and $W+$ LP treatments and between HP and $W+\mathrm{HP}$ treatments. However, $Q_{10}$ was largest for $\mathrm{HP}$ and $W+\mathrm{HP}$, mid-range for $\mathrm{LP}$ and $\mathrm{W}+\mathrm{LP}$, and least for $C$ and $W$.

Across all the 18 plots, $Q_{10}$ was positively correlated with $S M$ $(R=0.71, p<0.001)$, but negatively correlated with $T_{\mathrm{S}}(R=-0.63$, $p<0.01$ ), indicating that the temperature sensitivity of $R_{\mathrm{S}}$ was more closely related to SM than $T_{\mathrm{s}}$.

Previous studies showed that experimental warming reduces the temperature sensitivity of $R_{\mathrm{S}}$ (Luo et al., 2001; Zhou et al., 2006). However, our findings indicate that warming did not affect the temperature sensitivity of $R_{\mathrm{s}}$ partly owing to the experimentalwarming-induced drying of the soil (Xu et al., 2010). Values of $Q_{10}$ of $W+$ HP and $W+$ LP were significantly greater than that of $C$. The findings show that warming increased the temperature sensitivity of $R_{\mathrm{S}}$ when warming-induced soil drying was not limited.
Additionally, precipitation pulses increased the temperature sensitivity of $R_{\mathrm{s}}$, which was in line with the results of previous studies (McCulley et al., 2007). Therefore, water availability regulated the temperature sensitivity of $R_{\mathrm{s}}$.

In summary, precipitation pulses increased the temperature sensitivity of soil respiration, whereas experimental warming did not significantly affect the temperature sensitivity. The effects of experimental warming and precipitation pulses on soil respiration differed with water availability.

\section{Acknowledgements}

We thank the editor and reviewers for their insightful andvaluable comments, which greatly improved the quality of this manuscript.This work was funded by the National Natural Science Foundation of China (No. 41171084) and the Natural Science Foundation of Tibet Autonomous Region (Response of species richness and above-ground biomass to warming in the alpine meadow of Tibet).

\section{References}

Cable, J.M., Ogle, K., Williams, D.G., Weltzin, J.F., Huxman, T.E., 2008. Soil texture drives responses of soil respiration to precipitation pulses in the Sonoran Desert: implications for climate change. Ecosystems 11, 961-979.

Chen, S.P., Lin, G.H., Huang, J.H., He, M., 2008. Responses of soil respiration to simulated precipitation pulses in semiarid steppe under different grazing regimes. J. Plant Ecol. UK 1, 237-246.

Fu, G., Zhou, Y.T., Shen, Z.X., Zhang, X.Z., Shi, P.L., He, Y.T., Wu, J.S., 2010. Relationships between ecosystem respiration and environmental factors of alpine grazing meadows along an altitudinal gradient ( $4300 \sim 4700 \mathrm{~m})$. Ecol. Environ. Sci. 19 , 2789-2794 (in Chinese with English abstract).

Fu, G., Shen, Z., Zhang, X., Zhou, Y., 2012. Response of soil microbial biomass to shortterm experimental warming in alpine meadow on the Tibetan Plateau. Appl. Soil Ecol. 61, 158-160.

Fu, G., Zhang, X., Zhang, Y., Shi, P., Li, Y., Zhou, Y., Yang, P., Shen, Z., 2013. Experimental warming does not enhance gross primary production and above-ground biomass in the alpine meadow of Tibet. J. Appl. Remote Sens. 7 doi:http://dx.doi.org/10.1117/1.JRS.7.073505.

Fu, G., Zhang, X.Z., Yu, C.Q., Shi, P.L., Zhou, Y.T., Li, Y.L., Yang, P.W., Shen, Z.X., 2014a. Response of soil respiration to grazing in an alpine meadow at three elevations in Tibet. Sci. World J. doi:http://dx.doi.org/10.1155/2014/265142.

Fu, G., Shen, Z.X., Sun, W., Zhong, Z.M., Zhang, X.Z., Zhou, Y.T., 2014b. A meta-analysis of the effects of experimental warming on plant physiology and growth on the Tibetan Plateau. J. Plant Growth Regul. doi:http://dx.doi.org/10.1007/s00344014-9442-0 in press.

Hao, Y.B., Wang, Y.F., Mei, X.R., Cui, X.Y., 2010. The response of ecosystem $\mathrm{CO}_{2}$ exchange to small precipitation pulses over a temperate steppe. Plant Ecol. 209, 335-347.

Huxman, T.E., Snyder, K.A., Tissue, D., Leffler, A.J., Ogle, K., Pockman, W.T., Sandquist, D.R., Potts, D.L., Schwinning, S., 2004. Precipitation pulses and carbon fluxes in semiarid and arid ecosystems. Oecologia 141, 254-268.

IPCC, 2013. Summary for policymakers. In: Stocker, T.F., Qin, D., Plattner, G.-K., Tignor, M., Allen, S.K., Boschung, J., Nauels, A., Xia, Y., Bex, V., Midgley, P.M. (Eds.), Climate Change 2013: The Physical Science Basis. Contribution of Working Group to the Fifth Assessment Report of the Intergovernmental Panel on Climate Change. Cambridge University Press, Cambridge, United Kingdom/New York, USA.

Lellei-Kovács, E., Kovács-Láng, E., Kalapos, T., Botta-Dukát, Z., Barabás, S., Beier, C., 2008. Experimental warming does not enhance soil respiration in a semiarid temperate forest-steppe ecosystem. Commun. Ecol. 9, 29-37.

Liu, W.X., Zhang, Z., Wan, S.Q., 2009. Predominant role of water in regulating soil and microbial respiration and their responses to climate change in a semiarid grassland. Global Change Biol. 15, 184-195.

Lu, M., Zhou, X.H., Yang, Q., Li, H., Luo, Y.Q., Fang, C.M., Chen, J.K., Yang, X., Li, B., 2013. Responses of ecosystem carbon cycle to experimental warming: a metaanalysis. Ecology 94, 726-738.

Luo, Y.Q., Wan, S.Q., Hui, D.F., Wallace, L.L., 2001. Acclimatization of soil respiration to warming in a tall grass prairie. Nature 413, 622-625.

Marion, G.M., Henry, G.H.R., Freckman, D.W., Johnstone, J., Jones, G., Jones, M.H., Levesque, E., Molau, U., Molgaard, P., Parsons, A.N., Svoboda, J., Virginia, R.A. 1997. Open-top designs for manipulating field temperature in high-latitude ecosystems. Global Change Biol. 3, 20-32.

McCulley, R.L., Boutton, T.W., Archer, S.R., 2007. Soil respiration in a subtropical savanna parkland: response to water additions. Soil Sci. Soc. Am. J. 71, 820-828.

Munson, S.M., Benton, T.J., Lauenroth, W.K., Burke, I.C., 2010. Soil carbon flux following pulse precipitation events in the shortgrass steppe. Ecol. Res. 25, 205-211. 
Raich, J.W., Schlesinger, W.H., 1992. The global carbon dioxide flux in soil respiration and its relationship to vegetation and climate. Tellus Ser. B-Chem. Phys. Meteorol. 44, 81-99.

Rustad, L.E., Campbell, J.L., Marion, G.M., Norby, R.J., Mitchell, M.J., Hartley, A.E. Cornelissen, J.H.C., Gurevitch, J., Gcte, N., 2001. A meta-analysis of the response of soil respiration, net nitrogen mineralization, and aboveground plant growth to experimental ecosystem warming. Oecologia 126, 543-562.

Shi, P.L., Sun, X.M., Xu, L.L., Zhang, X.Z., He, Y.T., Zhang, D.Q., Yu, G.R., 2006. Net ecosystem $\mathrm{CO}_{2}$ exchange and controlling factors in a steppe - Kobresia meadow on the Tibetan Plateau. Sci. China Ser. D 49, 207-218.

Sponseller, R.A., 2007. Precipitation pulses and soil $\mathrm{CO}_{2}$ flux in a Sonoran Desert ecosystem. Global Change Biol. 13, 426-436.
Wu, Z.T., Dijkstra, P., Koch, G.W., Penuelas, J., Hungate, B.A., 2011. Responses of terrestrial ecosystems to temperature and precipitation change: a metaanalysis of experimental manipulation. Global Change Biol. 17, 927-942.

Xu, Z.F. Wan, C.A., Xiong, P., Tang, Z., Hu, R., Cao, G., Liu, Q., 2010. Initial responses of soil $\mathrm{CO}_{2}$ efflux and $\mathrm{C}, \mathrm{N}$ pools to experimental warming in two contrasting forest ecosystems, Eastern Tibetan Plateau, China. Plant Soil 336, 183-195.

Yu, C.Q., Shen, Z.X., Zhang, X.Z., Sun, W., Fu, G., 2014. Response of soil C and N dissolved organic $C$ and $N$, and inorganic $N$ to short-term experimental warming in an alpine meadow on the Tibetan Plateau. Sci. World J. doi:http:// dx.doi.org/10.1155/2014/152576.

Zhou, X.H., Sherry, R.A., An, Y., Wallace, L.L., Luo, Y.Q., 2006. Main and interactive effects of warming, clipping, and doubled precipitation on soil $\mathrm{CO}_{2}$ efflux in a grassland ecosystem. Global Biogeochem. Cycles 20, GB1003. doi:http://dx.doi. org/10.1029/2005GB002526. 